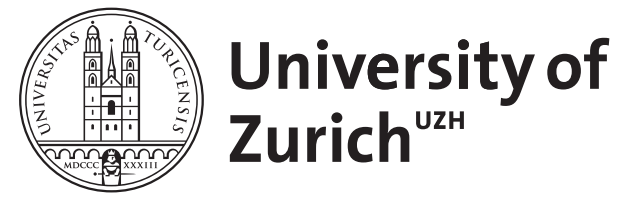

\title{
Direct democracy in Switzerland
}

Braun Binder, Nadja

Posted at the Zurich Open Repository and Archive, University of Zurich ZORA URL: https://doi.org/10.5167/uzh-141869

Book Section

Originally published at:

Braun Binder, Nadja (2008). Direct democracy in Switzerland. In: Beramendi, Virginia; et al. Direct Democracy. The International IDEA Handbook. Stockholm: Institute for Democracy and Electoral Assistance, 26-33. 


\title{
CASE STUDY
}

\section{Direct democracy in Switzerland}

\author{
Nadja Braun*
}

\section{Historical background}

The historical roots of direct democracy in Switzerland can be found in pre-modern forms of democracy. There was a living culture of popular assembly democracy and the federative referendum (a referendum that can be triggered by federative entities) dating back to the Middle Ages. Inspiration for direct democracy in Switzerland can also be found in the experience and the ideas of the American and even more of the French revolutions.

The cornerstones of the history of modern direct democracy at the national level are the introduction of the citizens' initiative for a total revision of the constitution and the mandatory constitutional referendum in 1848; of the optional referendum in 1874; and of the citizens' initiative in 1891. After 1891, direct democracy was further extended. The referendum on international treaties was introduced in 1921, and extended in 1977 and 2003. It allows citizens to be involved in decisions on foreign policy. The creation of the so-called resolutive referendum in 1949 restricted the ability of the Federal Assembly to protect decisions from exposure to referendum by declaring them to be 'emergency measures' (in the 1930s the government had used the emergency clause to systematically avoid referendums). The 'double yes' option with a deciding question where there is an initiative and a counter-proposal was introduced in 1987 and extended in 2003.

\section{Direct democracy procedures and legal provisions}

Switzerland is a federative state with 26 cantons (individual constituent states) and around 2,740 communes. Swiss voters have the right to cast their votes at the federal, cantonal and local levels. On average, four times a year there are referendums at all three levels.

*The opinions expressed in this case study are those of the author and do not reflect any official statement. 
The two main pillars of direct democracy in Switzerland are the citizens' initiative and the citizens' demand (optional/popular referendum).

\section{The legislative framework at the national level}

All Swiss citizens, whether living in Switzerland or abroad, who have reached the age of 18 and who are not disqualified on grounds of mental incapacity are entitled to vote in referendums (article 136 of the Swiss federal constitution (FC)). The issues that the people are called to vote on at the federal level are set out in the constitution (articles 138-142 FC). There are no quorum requirements such as a turnout quorum for a referendum to be valid.

The outcome of a referendum - be it an optional or a mandatory referendum is always binding (articles 142 and 195 FC). A basic distinction is made between mandatory and optional referendums.

A mandatory referendum must be held (article $140 \$ 1 \mathrm{FC}$ )

- in the event of a total or partial revision of the federal constitution;

- to join a collective security organization (e.g. the United Nations) or a supranational community (e.g. the EU); or

- to introduce urgent federal legislation without the required constitutional basis and which will be in force for longer than a year.

Such a decision requires the approval of both a popular majority and the majority of the cantons. A popular majority means a simple majority of those voting (article $142 \$ 1 \mathrm{FC}$ ). A majority of the cantons is achieved when the popular vote has been in favour of the proposal in a majority of cantons (article $142 \$ 3 \mathrm{FC}$ ). In calculating the majority, the results in six - out of a total of 26 - cantons each count as half a cantonal vote (article $142 \$ 4 \mathrm{FC)}$.

A referendum is also mandatory (article $140 \$ 2$ FC)

- for citizens' initiatives aimed at a total revision of the federal constitution;

- for citizens' initiatives aimed at a partial revision of the federal constitution which were presented as a general proposal and have been rejected in the Federal Assembly; and

- in order to reach a decision where the Federal Council (the government) and the National Council and the Council of States (the parliament) have disagreed as to whether a total revision of the federal constitution should take place or not.

In the latter three cases, the referendum is decided by a simple majority of the voters.

Swiss citizens who are entitled to vote can propose a partial or total revision of the constitution (articles 138 and 139 FC). Before a citizens' initiative can be officially validated, the signatures of 100,000 citizens who are entitled to vote (corresponding to approximately 2 per cent of the electorate) have to be gathered within 18 months. 
A citizens' initiative can be formulated as a general proposal or presented as a fully worked-out text. If the initiative is qualified, a referendum on it is mandatory.

An optional referendum takes place when it is requested within 100 days after the official publication of a statute either by 50,000 citizens (corresponding to approximately 1 per cent of the Swiss electorate) entitled to vote or by eight cantons. The following can be the subject of an optional referendum (article $141 \mathrm{FC})$ :

- federal laws;

- federal laws declared urgent with a validity exceeding one year;

- federal decrees to the extent that the constitution or the law foresee this; and

- international treaties which

(1) are of unlimited duration and may not be terminated;

(2) provide for the entry into an international organization

(e.g. International IDEA); or

(3) contain important legislative provisions or if their implementation requires provisions in federal laws.

The relevant law, decree or international treaty is approved if the people vote in favour of it (popular majority).

\section{The legislative framework at the cantonal and communal levels}

The instruments of initiative and referendum are available to Swiss voters not only at the national (federal) level, but also at the cantonal (regional) and communal (local) levels. Because each canton can choose its own way of allowing citizens to participate, there are extra possibilities: in addition to the constitutional initiative and the legislative referendum, all the cantons except Vaud also have the so-called finance referendum (see the table).

Another important instrument in the cantons is the obligatory legislative referendum, and in the communes the administrative referendum. Some cantons and communes link the referendum question with a popular counter-proposal (the so-called 'constructive referendum'). In the canton of Zurich there is the individual (agenda) initiative. In addition, citizens in several cantons have the right of recall of the administration. In other words, the lower the political level, the more opportunities citizens have to be directly involved in decision making.

\section{The regulatory framework governing direct democracy instruments}

In Switzerland, federal elections and federal direct democracy instruments are managed by the executive branch through the Federal Chancellery. However, the Federal Chancellery (national level) does not do this on its own, but jointly with the 26 cantonal electoral management bodies. 


\section{The organization of referendum votes}

The national polling days are appointed according to the rules laid down in article 10 of the Federal Law on Political Rights (FLP) of 17 December 1976 and article 2a of the Decree on Political Rights (DPR) of 24 May 1978). Federal referendum votes are not held during federal elections. A minimum of four months before polling day, the Federal Council (government) determines which proposals are to be submitted to the vote. The Federal Chancellery provides the cantons with the proposals to be submitted to a vote of the people and the ballot papers (article 11 FLP).

The Federal Council explains each proposal that is put to the vote in a so-called referendum booklet. It has to include the arguments of the committee responsible for the initiative or referendum (article 11 FLP). It is published by the Federal Chancellery in the four official languages and sent to the cantons for distribution to all eligible voters.

Each canton is responsible for the conduct of the vote within its own territory and has its own regulations (article 10 FLP). These regulations sometimes vary considerably. For example, four cantons have one or more centralized electoral registers, while the other 22 cantons have decentralized registers, that is, the communes keep the electoral registers.

The federal law requires that all voters receive the documents required in order to cast a valid vote at a minimum three and at the earliest four weeks prior to the polling day (article 11 FLP). The cantons have to execute this provision but the way they do this is up to them and also depends - among other things - on whether the canton or a commune in that canton decides to organize another referendum vote on the same day.

The management of the polling stations is also organized by the cantons or communes. After the vote, the cantons collect reports on the popular ballots from each polling station, compile the provisional results from the entire canton, and notify the Federal Chancellery of the results. The Federal Chancellery then validates the results and prepares the decision of the Federal Council, which determines the results of the overall vote.

\section{Administering citizens' demands (popular/optional referendums)}

The request for a popular referendum must be submitted to the Federal Chancellery before expiry of the referendum period, furnished with the required number of signatures and the certificates of eligibility to vote (article 59a FLP). Certificates of eligibility to vote are issued by cantonal or communal offices (article 59a FLP). These offices certify that the signatories are eligible to vote on federal matters. After expiry of the referendum period (100 days), the Federal Chancellery checks the validity of the signature lists and establishes whether the signature list contains the required number of valid signatures.

\section{Administering citizens' initiatives}

Prior to the start of the collection of signatures, the Federal Chancellery checks the 
signature list and declares in a ruling whether the signature list corresponds to the form prescribed by law (article 69 FLP). This preliminary check by the Federal Chancellery includes checking whether the title of an initiative is misleading, or if it contains commercial advertising or personal publicity or gives rise to confusion; and examining whether the text of the initiative is the same in all the official languages. This usually means that the Chancellery translates the text of the initiative.

The Federal Chancellery does not check the content or wording of the initiative text. Both the title and the text of a citizens' initiative are determined by the proponents of the initiative. However, the proponents do not have an entirely free hand: they must bear in mind certain restrictions on what can be proposed arising from national and international law. The constitution states that, in the case of a popular initiative for a partial revision of that constitution, 'If an initiative does not respect the principle of unity of form, the principle of unity of subject matter, or mandatory rules of international law, the Federal Parliament shall declare the initiative invalid, in whole or in part' (cf. article $139 \$ 3 \mathrm{FC}$ ).

After the preliminary check, the Federal Chancellery publishes the title and text of the initiative, together with the names of the authors (i.e. the members of the initiative committee) in the Official Federal Gazette (article 69 FLP). Starting from the day of publication in the Official Federal Gazette, the initiative committee has to collect 100,000 signatures and get the certificates of eligibility to vote of the signatures on the signature lists from the cantonal/communal offices within 18 months.

After expiry of the period allowed for the collection of signatures, the Federal Chancellery checks the validity of the signature lists and establishes whether the popular initiative contains the required number of valid signatures. The Federal Chancellery publishes the ruling on the success of the signature lists in the Official Federal Gazette together with details of the numbers of valid and invalid signatures for each canton (article 72 FLP).

\section{The financing of the use of direct democracy instruments}

In Switzerland, there is no public assistance for campaigners. The initiative or referendum committee is granted space (one page) in the official voters' pamphlet.

There has been a debate in recent years over the financing of referendum campaigns. According to one political scientist, Claude Longchamp, it takes 'around 10 million francs' to organize a professional national citizens' initiative from the initial launch through the actual campaign to tying up all the loose ends after the vote. On the other hand, the example of the 'Sunday Initiative' shows that it can be done with considerably less money: although the group campaigning for 'four car-free Sundays per year' had no more than 50,000 Swiss francs (CHF) with which to campaign, they still managed to get 37.6 per cent of the votes. Even in those cases where wealthy interest groups are involved, there is no evidence that money can directly influence referendum results in Switzerland. Quite the opposite: there are plenty of cases where, despite the spending of large amounts of money, voters went against the majority of the political or financial elites. 


\section{The use of direct democracy in Switzerland}

\section{How direct democracy procedures have been used and on what issues}

The tools of direct democracy are growing in popularity. Since 2000, an average of 10.8 national issues have been voted on per year, compared to 10 in 1990-99 and 6.2 in $1980-89$.

Between 1980 and the time of writing (June 2008), a total of 200 constitutional initiatives were started at the national level. Of these 200, 73 did not achieve a sufficient number of valid signatures. Of the 127 initiatives that did achieve the necessary number of valid signatures, 82 were voted on, 29 were withdrawn by the initiative committee shortly before the vote, two were declared invalid by the parliament, and 14 are currently pending at an earlier stage of the process. Over the same period, at the national level, 72 citizen-demanded referendums achieved the necessary number of valid signatures and were voted on.

The issues on which the people are called to vote at the federal level are set out in the constitution (articles 138-142 FC). Except for the invalidity criteria for initiatives, no topics are excluded from a vote - provided the formal conditions are fulfilled.

\section{Coverage of the use of direct democracy instruments by the media}

The public broadcasting stations are in a rather special position as regards their reporting of referendum processes: unlike in the private media, the chief editors of the three national radio and television stations make no specific recommendations. Although there is no advertising on public radio, television is partially financed by advertising. However, political advertising is banned. In their dealings with initiatives and referendums, the public broadcast media follow an internally devised code of conduct - the "handbook of journalism' - which is designed to ensure accuracy, impartiality and fairness.

\section{Voter participation in direct democracy votes, and an analysis of the political dynamic of campaigns related to such votes}

Until the end of World War II, at the national level, average voter turnout was around 50 per cent. Between 1960 and the mid-1980s it fell to below 40 per cent, but since the late 1980s it has increased again - up to around 45 per cent. The single most important factor for mobilizing voters is the referendum topic. Accordingly participation varies from one referendum to the next.

Voter education regarding the subject of a referendum is done by means of the referendum booklet. The little red booklet is mailed out to all registered electors, together with the voting slips and the certificate of entitlement to vote. Initiative and referendum committees can draft their own arguments and have them included in the booklet. The government recommends whether the initiative or referendum should be accepted or rejected. The government is not actually allowed to campaign, but it is its duty to give information to the voters. The fact that the four major political parties are represented in the government ensures that the information presented to the voters is balanced. 


\section{The experience of Switzerland: lessons learned, problems and controversies regarding the use of direct democracy procedures}

The number of signatures required for citizens' initiatives and optional referendums and the collection deadlines have been the subject of political debate for many years. On several occasions the government has proposed raising the signature quorums for initiatives and referendums, and initiative committees have demanded a reduction in the time allowed to the authorities to process initiatives. The proposal to cut the time allowances suffered a clear defeat at the ballot box, and the plan to increase the signature quorums did not even get through the parliament. Although the signature quorum remained the same, it has not become any easier to collect the 100,000 signatures required for a national citizens' initiative. Quite the opposite: it has actually become harder. The trend towards more postal voting has adversely affected the traditional method of collecting signatures outside voting centres.

In terms of the modernization of direct democracy, the government is also looking at the possibility of using the Internet. The first regular referendum at which e-voting was allowed took place on 14 January 2003 in the small community of Anières in the canton of Geneva. Since then several tests were carried out during national referendums in the cantons of Geneva, Neuchâtel and Zurich.

Figure 1. Voter turnout, 1995-2005

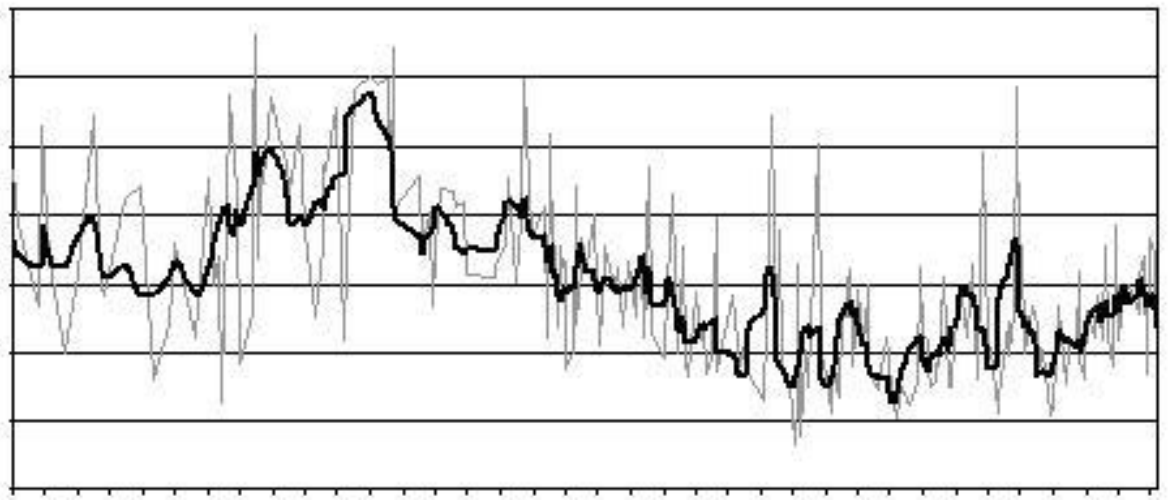

Nominal voter turnout Average voter turnout for 5 referendums 


\begin{tabular}{|c|c|c|c|c|c|c|c|c|}
\hline \multirow[b]{2}{*}{ Canton } & \multirow{2}{*}{ 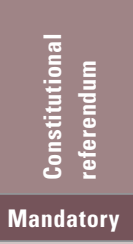 } & \multicolumn{2}{|c|}{ 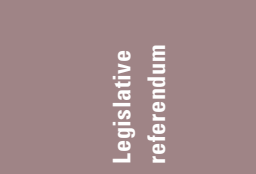 } & \multicolumn{2}{|c|}{ 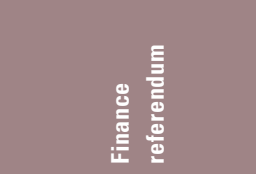 } & \multicolumn{2}{|c|}{ 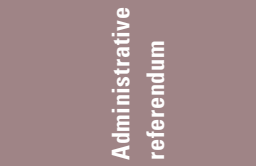 } & \multirow[t]{2}{*}{ 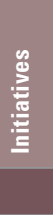 } \\
\hline & & Mandatory & Optional & Mandatory & Optional & Mandatory & Optional & \\
\hline Zurich & $\bullet$ & - & - & & - & & & - \\
\hline Bern & $\bullet$ & & • & & - & & $\bullet$ & $\bullet$ \\
\hline Lucerne & $\bullet$ & & - & - & - & & & - \\
\hline Uri & • & • & & • & • & & • & • \\
\hline Schwyz & - & - & - & - & & & & - \\
\hline Obwalden & $\bullet$ & & - & & - & & & - \\
\hline Nidwalden & $\bullet$ & & - & - & - & - & & - \\
\hline Glarus & $\bullet$ & - & & - & & - & & - \\
\hline Zug & - & & - & & - & & & - \\
\hline Freiburg & $\bullet$ & & - & $\bullet$ & - & & & - \\
\hline Solothurn & $\bullet$ & - & - & - & - & - & - & - \\
\hline Basle (city) & $\bullet$ & & - & & - & & $\bullet$ & - \\
\hline Basle (county) & $\bullet$ & - & - & & - & & & - \\
\hline Schaffhausen & - & - & - & - & - & - & - & - \\
\hline $\begin{array}{l}\text { Appenzell } \\
\text { Ausserrhoden }\end{array}$ & • & • & • & • & 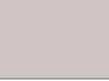 & & & • \\
\hline $\begin{array}{l}\text { Appenzell } \\
\text { Innerrhoden }\end{array}$ & $\bullet$ & - & 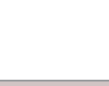 & - & - & & & - \\
\hline Sankt Gallen & - & & - & - & - & & & - \\
\hline Graubünden & • & & • & • & • & & & - \\
\hline Aargau & - & - & • & & - & & & - \\
\hline Thurgau & $\bullet$ & & • & - & - & & & - \\
\hline Ticino & • & & - & & - & & & - \\
\hline Vaud & $\bullet$ & • & - & & & & & - \\
\hline Valais & - & & - & & - & & & - \\
\hline Neuchâtel & - & & - & & - & & & - \\
\hline Geneva & - & & - & & - & & & - \\
\hline Jura & - & & • & - & • & & & • \\
\hline
\end{tabular}

Source: Swiss Federal Chancellery. 